\title{
Primacy of seascape connectivity effects in structuring coral reef fish assemblages
}

\author{
Andrew D. Olds*', Rod M. Connolly, Kylie A. Pitt, Paul S. Maxwell \\ Australian Rivers Institute - Coast and Estuaries, School of Environment, Griffith University, Gold Coast, Queensland 4222, \\ Australia
}

\begin{abstract}
Connectivity has fundamental consequences for the productivity, persistence and management of coral reefs. The area and position of adjacent mangroves and seagrass can affect the demography of reef fish populations and the composition of reefal assemblages. To date, no studies have attempted to partition the influences of these habitats on reef fish assemblages. We used an exploratory seascape approach to separate the effects of connectivity with mangroves and seagrass on reef fish in Moreton Bay, Australia. We then compared the performance of seascape connectivity and reef complexity (i.e. coral cover, rugosity and area) in structuring these assemblages. Our results suggest a hierarchy of seascape connectivity effects, with reef fish assemblages being primarily distinguished by isolation (i.e. separation distance) from mangroves and secondarily by proximity (an index incorporating habitat isolation and area) to seagrass. Importantly, measures of reef complexity were only useful in separating reef fish assemblages within levels of connectivity with mangroves and seagrass. We demonstrate that neighbouring mangroves and seagrasses can exert different effects on reef fish assemblages, with $25 \%$ of all species being primarily influenced by mangroves and a different $25 \%$ being affected by seagrass. These findings have important implications for the design of marine reserve networks. They show that position in the seascape can be of greater significance than reef area or complexity to the composition of reef fish assemblages and highlight the value of incorporating seascape connectivity into conservation planning.
\end{abstract}

KEY WORDS: Landscape $\cdot$ Mangrove $\cdot$ Seagrass $\cdot$ Fish $\cdot$ Nursery $\cdot$ Australia

Resale or republication not permitted without written consent of the publisher

\section{INTRODUCTION}

Coral reef seascapes are mosaics of seemingly disjointed habitat that are functionally connected by the movement and dispersal of organisms (Almany et al. 2009). Reefs lie within spatially heterogeneous seascapes (Pittman et al. 2011) that include other complex habitats, such as mangroves and seagrass. Reef organisms utilise a range of non-reef habitats during their lives, for example, as juvenile nurseries (e.g. Nagelkerken 2009), for foraging and sheltering (e.g. Valentine \& Heck 2005) or for spawning and dispersal (e.g. Jones et al. 2009). The characteristics of the seascape (e.g. composition, arrangement and proximity of nearby habitats), therefore, can have a major influence on the assemblages and population dynamics of organisms that inhabit coral reefs (e.g. Grober-Dunsmore et al. 2008). Connectivity between habitats may also confer reefs with resilience (Mumby \& Hastings 2008), which is the capacity to absorb recurrent natural perturbations and regenerate without slowly degrading or changing state (Hughes et al. 2010). Consequently, maintaining connectivity is now a focus for the management of marine reserves (McCook et al. 2009), and the protection of seascapes with high connectivity is recommended (e.g. Adams et al. 2006). However, the combined effects of overfishing, declining water quality, habitat loss and climate change have led to the degradation of many coral reefs and may have fundamentally 
altered connectivity within seascapes (Knowlton \& Jackson 2008, Bostrom et al. 2011). Accordingly, there is now a pressing need for the application of spatially explicit studies of connectivity in coral reef ecosystems (Wilson et al. 2010).

Broadly speaking, connectivity is a function of habitat area, quality and spatial arrangement and the dispersal capabilities of individual species (Hodgson et al. 2009). Landscape connectivity, which is the physical connectedness of patches in a particular landscape (Lindenmayer \& Fischer 2007), can be quantified using structural connectivity metrics, which describe the spatial arrangement of habitats from benthic habitat maps (Grober-Dunsmore et al. 2009). For example, Meynecke et al. (2008b) examined multiple connectivity metrics to determine that wetland connectivity explained the greatest proportion of variation in nearshore commercial fish catches in Queensland, Australia. This approach is assumed to provide reasonable surrogates for multi-species conservation, and its inherent simplicity gives it great appeal for conservation planning and assessment (Calabrese \& Fagan 2004).

The demographics of coral reef fish populations are influenced by the composition of the seascape and the spatial arrangement of habitat patches (reviewed by Grober-Dunsmore et al. 2009). This seascape connectivity can exert an influence across a range of scales, from 100s of metres for diel and tidal feeding movements (e.g. Grober-Dunsmore et al. 2007), to 10s of kilometres for ontogenetic migrations between habitats (e.g. Mumby 2006) and up to 1000s of kilometres for broader dispersal (e.g. Treml et al. 2008). Its implications for reef fish are best understood for the waters of the Caribbean, where the composition of assemblages and population demography are affected by linkages with seagrass (e.g. Grober-Dunsmore et al. 2008) and mangrove (e.g. Mumby et al. 2004) habitats. These connections can also influence other ecological aspects, namely the structure of reef food webs (e.g. Heck et al. 2008), the value of nonreef habitats as nurseries for juvenile reef fish (e.g. Nagelkerken 2009), the ecological processes on both reefs and adjacent habitats (e.g. Layman et al. 2007, Dorenbosch et al. 2009) and the performance of marine reserves (e.g. Huntington et al. 2010, Olds et al. 2012). In contrast to the Caribbean, there have been relatively few quantitative analyses of Pacific reef seascapes (Nagelkerken 2007, but see Unsworth et al. 2008 for an exception). Furthermore, no studies have yet attempted to partition the influences of connectivity with mangrove and seagrass habitats on the composition of reef fish assemblages.
Here, we adopted an exploratory seascape approach (sensu Grober-Dunsmore et al. 2008) to examine how seascape connectivity with mangrove and seagrass habitats affects reef fish assemblages in the Moreton Bay Marine Park in eastern Australia. Then, we contrasted the roles of seascape connectivity and reef complexity (i.e. coral cover, rugosity and area) in the composition of these assemblages. Moreton Bay is a large subtropical embayment south of the Great Barrier Reef (GBR) and adjacent to the city of Brisbane. It supports marginal, fringing coral reefs (Lybolt et al. 2011), dominated by massive Favia, Goniastrea and Goniopora colonies (Wallace et al. 2009). These reefs occur within a heterogeneous seascape that supports abundant adjacent seagrass and neighbouring mangroves (Stevens \& Connolly 2005) and provide a useful study area for examining the role of seascape connectivity in structuring reef fish assemblages. We tested the hypotheses (1) that connectivity with neighbouring mangroves and seagrass will affect different components of the reef fish assemblages and (2) that the effects of seascape connectivity will exceed those of reef complexity in structuring fish abundance in Moreton Bay. We anticipated mangroves to affect the abundance of snappers (Lutjanidae), groupers (Serranidae) and bream (Sparidae) on reefs and expected seagrass to influence the abundance of sweetlip (Haemulidae), emperors (Lethrinidae), parrotfish (Scaridae) and rabbitfish (Siganidae) (based on Nagelkerken 2009, Sheaves 2009, Unsworth \& Cullen 2010).

\section{MATERIALS AND METHODS}

\section{Seascape analysis}

We surveyed the fish and benthic assemblages of 16 fringing reefs in central Moreton Bay (Fig. 1), Australia $\left(27^{\circ} 15^{\prime} \mathrm{S}, 153^{\circ} 15^{\prime} \mathrm{E}\right)$, between December 2009 and April 2010. Seascape connectivity was quantified from existing benthic habitat maps for Moreton Bay (source: Queensland Department Environment and Resource Management) using ArcGIS (Environmental Systems Research Institute). Coral reefs, mangrove forests and seagrass meadows in the region have been mapped to a depth of $10 \mathrm{~m}$ based on field surveys and interpretation of satellite and aerial imagery, at a spatial resolution of $500 \mathrm{~m}^{2}$ (e.g. Dowling \& Stephens 2001, Roelfsema et al. 2009). Deeper benthic assemblages (to $50 \mathrm{~m}$ ) have been field mapped at a coarser $(5 \mathrm{~km})$ scale (Stevens \& Connolly 2005). These differences in map scale preclude the calcula- 


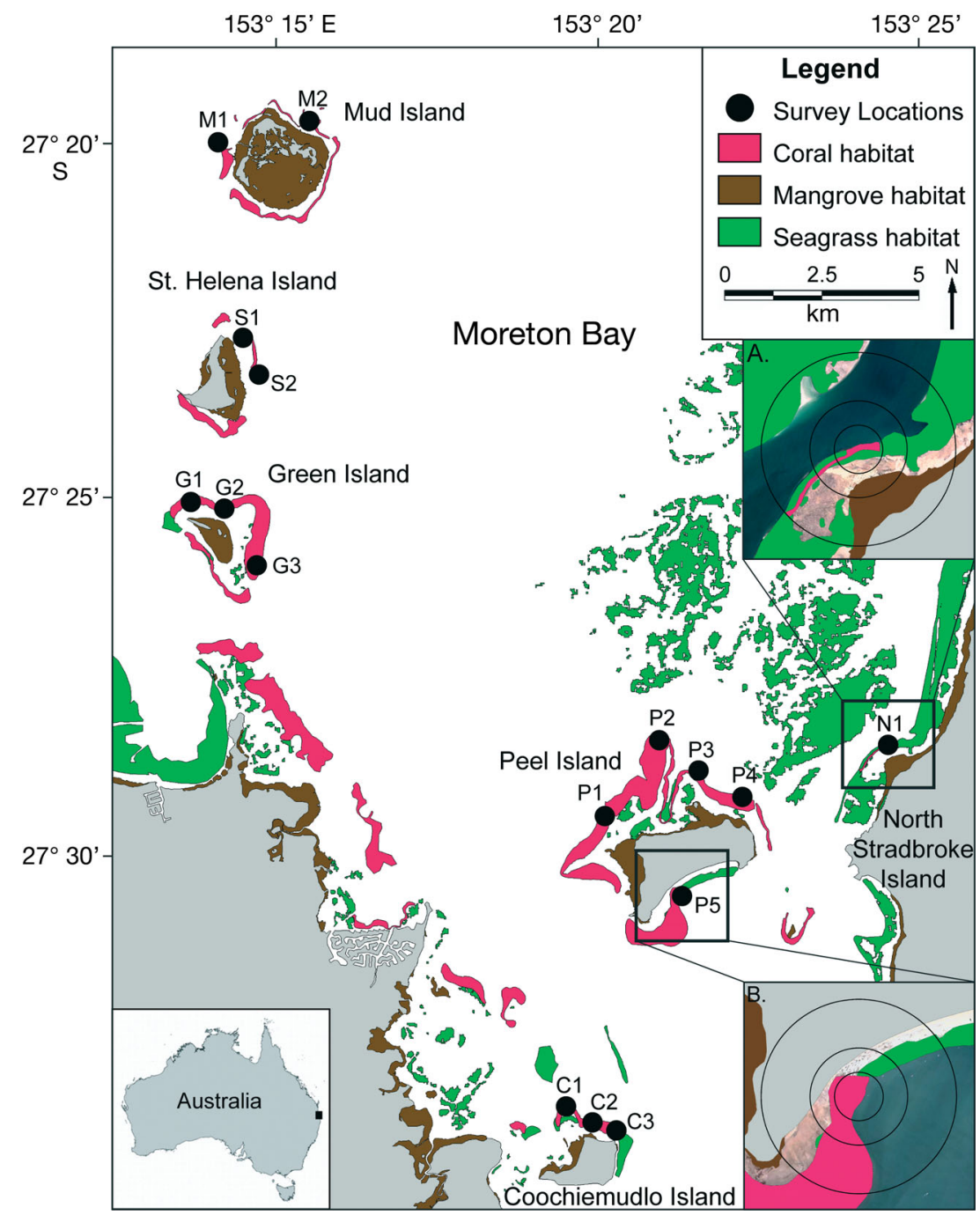

Fig. 1. Coral reef, seagrass and mangrove habitats of central Moreton Bay, Australia. Survey locations depicted as black dots over coral reef habitat. C: Coochiemudlo Island; G: Green Island; M: Mud Island; N: North Stradbroke Island; P: Peel Island; and S: St Helena Island. Insets: detailed seascapes and positioning of kernels around (A) Myora and (B) Horseshoe reefs

Mud and St Helena islands (Johnson \& Neil 1998). Five spatial pattern metrics (Fig. 2) (reviewed by Wedding et al. 2011) were used to describe connectivity in reef seascapes: (1) isolation, the edge-to-edge distance from reefs to nearest habitats (Moilanen \& Nieminen 2002), (2) area, the area of neighbouring habitats within kernels centred on each reef (Moilanen \& Nieminen 2002), (3) proximity index, which incorporates the isolation and area of neighbouring habitats within kernels centred on each reef (McGarigal et al. 2002), (4) connectivity index, which incorporates the isolation and area of both reefs and neighbouring habitats within kernels centred on each reef (Kindlmann \& Burel 2008) and (5) length of the connected edge (LCE), the length of shared edges connecting reefs and adjacent habitats (McGarigal et al. 2002).

Importantly, seascape studies need be scaled to the mobility of the species of interest (Grober-Dunsmore et al. 2009). We adopted a multi-scale analytical approach (sensu Pittman \& Brown 2011), which is appropriate when there is insufficient information on movement and habitat use patterns and it is likely that species respond to seascape structure at different scales. We quantified connectivity metrics at scales of 250, 500 and $1000 \mathrm{~m}$ in kernels centred on each reef survey location (Figs. $1 \& 2$ ). These scales were chosen to encompass the daily home

tion of spatial metrics across shallow and deep assemblages (sensu Kendall et al. 2011), and we focus on connectivity between shallow reefs, mangroves and seagrass. Seagrass communities support a heterogeneous mix of species but are dominated by Zostera muelleri (Skilleter et al. 2005). Sparse seagrass in the region declined in both cover and areal extent during the period between mapping and fish surveys (Lyons et al. 2011); consequently, all seagrass with <25\% cover (cf. Roelfsema et al. 2009) was omitted from the analysis. Mangrove forests are dominated by Avicennia marina, with similar composition and tidal inundation across most sites surveyed (Olds et al. 2012); however, rubble banks (resulting from the prior extraction of limestone) have altered the bathymetry at ranges of many adult bream, emperor, grouper, parrotfish, rabbitfish and snapper, which are large resident components of the fish assemblages of coral reef seascapes in the western Pacific (e.g. Sheaves 1993, Zeller et al. 2003, Chateau \& Wantiez 2009, Fox \& Bellwood 2011). Ideally, home ranges of other species would also be included when selecting a spatial context, but movement data are lacking for other fish families in the region. The minimum scale for calculating connectivity metrics (i.e. kernel radii of $250 \mathrm{~m}$ ) was restricted by the size of fish survey transects. It was not possible to examine seascape connectivity at larger scales to encompass ontogenetic shifts between juvenile nurseries (sensu Beck et al. 2001) and reef habitats (i.e. 10s of kilometres) (e.g. Nagel- 


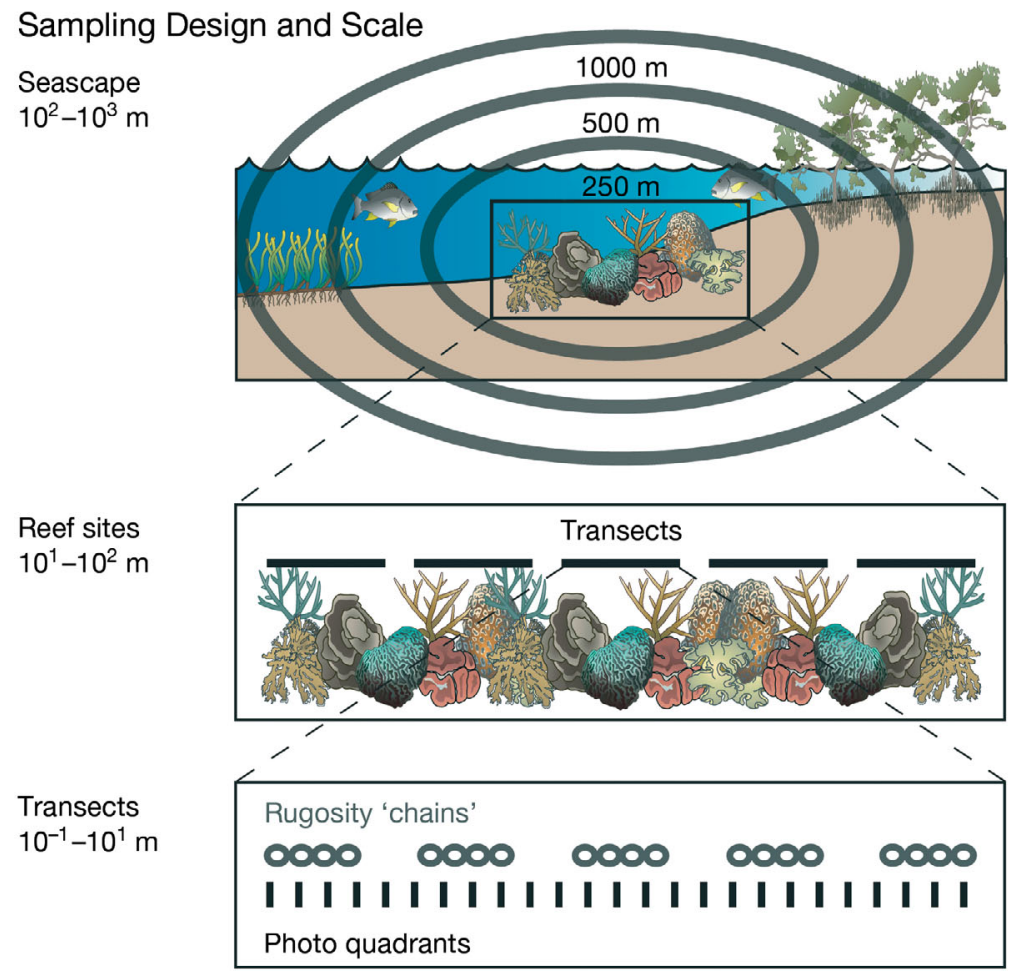

\section{Connectivity Metrics}
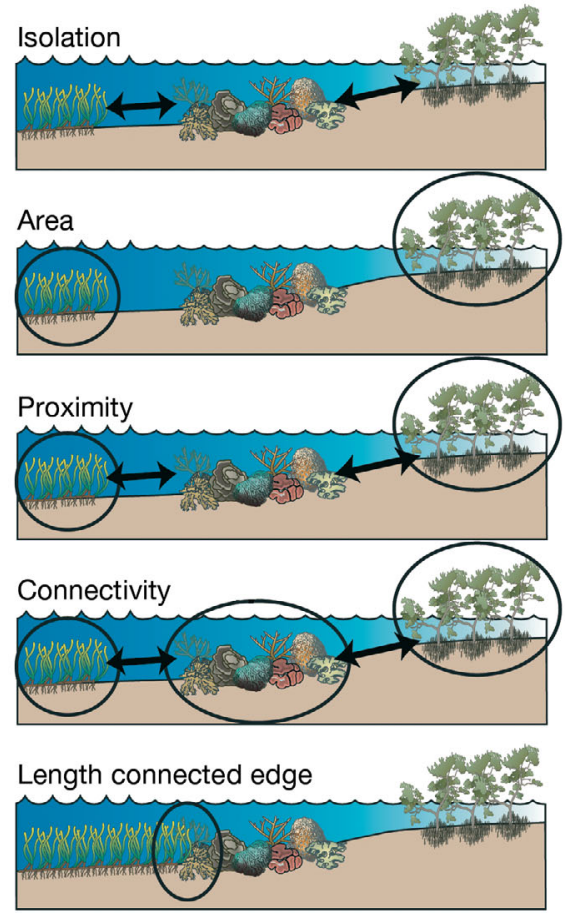

Fig. 2. Conceptual diagrams illustrating the sampling design (i.e. positioning of kernels around reefs and the nested scales of sampling) and the difference between seascape connectivity metrics (i.e. isolation, area, proximity index, connectivity index and length of the connected edge) (Symbols courtesy of the Integration and Application Network, ian.umces.edu/symbols/)

kerken 2009). The close proximity of reefs in the study area resulted in substantial overlap in the area of nursery habitats adjacent to reefs. This homogenised nursery connectivity metrics among sites at this broader (10s of kilometres) scale.

\section{Fish surveys}

Coral reef fish were surveyed using underwater visual census (UVC) (following Fulton et al. 2001). Five replicate $50 \times 4 \mathrm{~m}$ belt transects were censused at each site within $2 \mathrm{~h}$ of low tide, when intertidal mangroves and seagrass were dry and not accessible and fish were concentrated over subtidal reefs. Transects were positioned in series along each reef and separated by a minimum of $50 \mathrm{~m}$ (Fig. 2). Each census consisted of a diver swimming parallel to the reef slope and recording the species and abundance of all fish with total length (TL) $>5 \mathrm{~cm}$. All transects were surveyed by the same diver and positioned at depths of 1 to $3 \mathrm{~m}$ below the lowest astronomical tide. We examined the influence of seascape and coral reef variables on the composition of fish assemblages and assessed their effects on distribution of individual species to provide support for trends at the assemblage level.

\section{Benthic habitat assessments}

Coral reef rugosity and coral cover are important drivers of spatial variation in reef fish assemblages (e.g. Wilson et al. 2007) and were surveyed along the same belt transects used to quantify fish abundance, to describe intra-habitat variation in reef habitat among locations. Benthic assemblages were quantified by taking digital photographs of the benthos every $2 \mathrm{~m}$ along each transect from $0.5 \mathrm{~m}$ above the substrate (Fig. 2). Photographs were taken with a Canon Powershot digital camera in an Ikelite housing with an ultra wide-angle lens. Digital images were analysed for benthic cover using Coral Point Count v3.6 (Kohler \& Gill 2006). A grid of 25 points was randomly overlaid on each $1 \mathrm{~m}^{2}$ image, and the substrate underlying each point was classified as hard coral, soft coral, macroalgae, epilithic algae matrix (EAM), crustose coralline algae, coral rubble or sand. This broad classification precludes the detection of any relationships between fish assemblages and coral species composition; however, it was deemed appropriate for the fringing reefs of Moreton Bay, which support low coral diversity and are dominated by massive corals (Johnson \& Neil 1998, Wallace et al. 2009, Lybolt et al. 2011). Rugosity 
was assessed using the 'chain-link method' (Luckhurst \& Luckhurst 1978). Briefly, a 6 m chain was draped over the substrate every $10 \mathrm{~m}$ along each transect to follow the natural reef contour (Fig. 2). Rugosity ( $r$ ) was calculated as the ratio of distance along the reef surface contour (CD) to linear horizontal distance (LD) using $r=\mathrm{CD} / \mathrm{LD}$.

\section{Data analysis and distribution modelling}

Distributions of all recorded reef fish species were examined for relationships with seascape and coral reef variables using boosted regression trees (BRTs) (sensu Pittman \& Brown 2011). BRTs are non-parametric machine learning algorithms that provide for sophisticated regression analyses of complex responses and are optimised for high predictive performance (Elith et al. 2008). This technique differs from conventional regression in that, rather than fitting a single 'best' model, it fits an ensemble of simple regression tree models by iteratively fitting new trees to the residual errors of their predecessors (De'ath 2007). BRTs provide superior predictive performance over conventional modelling techniques, such as generalised additive models and linear regression (Knudby et al. 2010). They can fit non-linear relationships and are robust to colinearity among predictors, their power is not reduced by the presence of irrelevant variables, and they can model interaction and threshold effects (Pittman et al. 2009). This enables the data for each species to be analysed in a single model that includes all predictor variables across the 3 spatial scales. Models were implemented using the R dismo software package (R Core Development Team 2012) and optimised with slow learning rates $(0.0001$ to 0.001 ) and low tree complexities (2 to 4 ), using 10fold cross-validation (CV) (following Elith \& Leathwick 2011) (Appendix 1). Predictor variables used to model fish distributions included reef complexity variables (i.e. coral cover, reef rugosity and reef area), seascape connectivity metrics (i.e. isolation, area, proximity, connectivity and LCE of mangroves and seagrass) and location (to account for the spatial structure of sites around islands). Interaction strength was estimated using the techniques of Elith et al. (2008). The relative contribution (\%) of predictor variables to the model's predictive power and the overall patterns in fish abundance was determined using the variable importance score (Elith et al. 2008). Model discrimination was assessed using the area under the receiver operating characteristic curve (AUC) statistic. We followed Pittman and Brown (2011) and considered
AUC values of $>0.9$ outstanding, 0.8-0.9 excellent, $0.7-0.8$ acceptable and a value of 0.5 as the predictive ability that could be achieved by chance alone.

Fish assemblage data were examined using the BEST and LINKTREE procedures with PRIMER (PRIMER-E). The BEST routine was used to identify seascape and coral reef variables that best explained patterns of similarity in reef fish assemblages (Clarke et al. 2008). Relationships between these variables and fish assemblages were then further examined using the LINKTREE test, which constructs a hierarchical dendrogram to relate environmental variables and patterns in assemblage composition, with each division being characterised by one or more variables that appear responsible for discriminating different assemblage groupings (Clarke et al. 2008). LINKTREE maximises the degree of separation between the 2 groups of samples formed at each division using the ANOSIM R statistic. Groups are, therefore, defined by similarities in their assemblage structure and separated by inequalities in associated environmental variables. Coherent groups of samples in the dendrogram were defined by SIMPROF tests at a significance level of 0.01 . SIMPROF is a permutation test (we used 999 permutations) for evidence of multivariate structure among samples in clusters with no a priori grouping (Clarke et al. 2008). Analyses were applied to Bray-Curtis similarity matrices calculated on square-root transformed abundance data. Variables included in the environmental data matrix were the area of coral reef, reef rugosity, coral cover, reef isolation from mangroves and reef proximity to seagrass. Connectivity metrics were chosen on the basis of their performance in describing patterns in species abundance. The similarity matrix of environmental variables was calculated using normalised Euclidean distances.

\section{RESULTS}

\section{Reef fish species and seascape connectivity}

BRT provided acceptable (or better) model predictions for the distribution of 28 fish species (Table 1). Reef complexity variables were important predictors for the distribution of 14 species, including 5 butterflyfish (Chaetodontidae), 2 surgeonfish (Acanthuridae), 2 wrasse (Labridae), 2 damselfish (Pomacentridae), a cardinalfish (Apogonidae), a morwong (Cheilodactylidae) and a threadfin bream (Nemipteridae). Coral cover was of primary importance to all species and contributed between $23 \%$ (Apogon li- 
Table 1. Important seascape connectivity and reef complexity metrics contributing to boosted regression tree (BRT) models of reef fish distribution, contributions of each predictor (\%) and pairwise interactions between predictor variables. AUC: area under the receiver operating characteristic curve; CA: reef area; CC: coral cover; CR: reef rugosity; MA: mangrove area; MC: mangrove connectivity; MI: mangrove isolation; SA: seagrass area; SI: seagrass isolation; SL: seagrass length of connected edge (LCE); SP: seagrass proximity. Subscript numbers denote scale (metres). Only species with fitted models with acceptable predictive performance (i.e. AUC $\geq 0.7$ ) are reported; all predictor variables that contributed $>10 \%$ to BRT models are reported. Interaction values indicate degree of departure from additive effects, with zero indicating no interaction is present; interactions reported for all values $>1$

\begin{tabular}{|c|c|c|c|c|c|c|}
\hline Species & Family & AUC & Predictor 1 & Predictor 2 & Predictor 3 & Interactions \\
\hline \multicolumn{7}{|l|}{ Reef influence } \\
\hline Abudefduf bengalensis & Pomacentridae & 0.860 & $\mathrm{CC}(34)$ & CR (20) & $\mathrm{SP}_{500}(11)$ & \\
\hline Acanthurus dussumieri & Acanthuridae & 0.707 & $\mathrm{CC}(40)$ & CR (12) & & \\
\hline Apogon limenus & Apogonidae & 0.867 & $\mathrm{CC}(23)$ & CR (13) & $\mathrm{SP}_{500}(10)$ & \\
\hline Chaetodon auriga & Chaetodontidae & 0.826 & CC (39) & & & \\
\hline Chaetodon flavirostris & Chaetodontidae & 0.886 & $\mathrm{CC}(54)$ & & & CC \& MI (1.9) \\
\hline Chaetodon melannotus & Chaetodontidae & 0.833 & $\mathrm{CC}(31)$ & CR (21) & $\mathrm{SL}_{1000}(11)$ & \\
\hline Chaetodon plebeius & Chaetodontidae & 0.824 & $\mathrm{CC}(40)$ & CR (25) & & \\
\hline Cheilodactylus vestitus & Cheilodactylidae & 0.881 & $\mathrm{CC}(38)$ & CR (17) & $\mathrm{SP}_{500}(14)$ & $\mathrm{CR} \& \mathrm{SP}_{500}(1.5)$ \\
\hline Chelmon rostratus & Chaetodontidae & 0.891 & $\mathrm{CC}(28)$ & CR (21) & $\mathrm{CA}_{1000}(13)$ & \\
\hline Choerodon schoenleinii & Labridae & 0.704 & $\mathrm{CC}(30)$ & SI (15) & $\mathrm{SA}_{1000}(12)$ & \\
\hline Parma oligolepis & Pomacentridae & 0.904 & $\mathrm{CC}(27)$ & $\mathrm{CA}_{500}(16)$ & & $\mathrm{CC} \& \mathrm{SA}_{1000}(1.6)$ \\
\hline Pentapodus paradiseus & Nemipteridae & 0.708 & $\mathrm{CC}(31)$ & $\mathrm{CA}_{1000}(10)$ & CR (10) & CC \& CR (2.0) \\
\hline Prionurus microlepidotus & Acanthuridae & 0.715 & $\mathrm{CC}(33)$ & CR (11) & & $\mathrm{CC} \& \mathrm{SP}_{500}$ \\
\hline Thalassoma lunare & Labridae & 0.903 & CC (69) & & & $\mathrm{CC} \& \mathrm{SC}_{250}(2.3)$ \\
\hline \multicolumn{7}{|l|}{ Mangrove influence } \\
\hline Acanthopagrus australis & Sparidae & 0.860 & $\mathrm{MC}_{500}(36)$ & MI (11) & $\mathrm{CC}(11)$ & $\mathrm{MC}_{500} \& \mathrm{MA}_{500}(3.4)$ \\
\hline Atherinomorus vaigiensis & Atherinidae & 0.847 & $\mathrm{MC}_{500}(54)$ & MI (18) & & \\
\hline Epinephelus coioides & Serranidae & 0.827 & $\mathrm{MC}_{1000}(35)$ & MI (11) & $\mathrm{CC}(10)$ & \\
\hline Gerres subfasciatus & Gerridae & 0.927 & MI (33) & $\mathrm{MC}_{500}(13)$ & $\mathrm{CC}(12)$ & MI \& CR (10.4) \\
\hline Lutjanus fulviflamma & Lutjanidae & 0.895 & $\mathrm{MA}_{500}(23)$ & CR (13) & $\mathrm{SL}_{250}(11)$ & \\
\hline Lutjanus russelli & Lutjanidae & 0.892 & $\mathrm{MC}_{1000}(35)$ & CC (13) & $\mathrm{MC}_{500}(11)$ & $\begin{array}{c}\mathrm{CC} \& \mathrm{CR}(1.4) \\
\mathrm{MC}_{1000} \& \mathrm{CC}(1.1)\end{array}$ \\
\hline Siganus fuscescens & Siganidae & 0.871 & $\mathrm{MC}_{500}(24)$ & MI (13) & CC (11) & \\
\hline \multicolumn{7}{|l|}{ Seagrass influence } \\
\hline Choerodon cephalotes & Labridae & 0.728 & $\mathrm{SP}_{500}(24)$ & $\mathrm{SA}_{1000}(12)$ & $\mathrm{CA}_{500}(11)$ & \\
\hline Diagramma labiosum & Haemulidae & 0.820 & $\mathrm{SP}_{1000}(24)$ & CR (13) & & \\
\hline Lethrinus laticaudis & Lethrinidae & 0.878 & $\mathrm{SP}_{1000}(39)$ & $\mathrm{SA}_{1000}(18)$ & $\mathrm{CC}(11)$ & \\
\hline Lethrinus nebulosus & Lethrinidae & 0.837 & $\mathrm{SL}_{1000}(35)$ & SI (15) & CC (14) & \\
\hline Monacanthus chinensis & Monacanthidae & 0.823 & $\mathrm{SP}_{500}(29)$ & $\mathrm{SA}_{1000}(15)$ & CC (14) & $\begin{array}{c}\mathrm{SP}_{500} \& \mathrm{CC}(8.5) \\
\text { CC \& CR (3.5) }\end{array}$ \\
\hline Scarus ghobban & Scaridae & 0.865 & SI (33) & $\mathrm{CC}(11)$ & $\mathrm{SA}_{1000}(10)$ & \\
\hline Sphyraena obtusata & Sphyraenidae & 0.862 & $\mathrm{SP}_{500}(57)$ & CR (11) & & $\mathrm{SP}_{500} \& \mathrm{CR}(7.0)$ \\
\hline
\end{tabular}

menus) and $69 \%$ (Thalassoma lunare) to the distribution of each species. Reef rugosity was of secondary importance for 9 species (contributing 10 to $25 \%$ ). Reef area (at the 500 and $1000 \mathrm{~m}$ scales) was also significant to 3 species (contributing 10 to $16 \%$ ). In addition to reef effects, seagrass connectivity (i.e. area, isolation, LCE and proximity) was of low importance (contributing $<15 \%$ ) to 5 species. Most species demonstrated a clear preference for reefs with high coral cover and rugosity (e.g. Acanthurus dussumieri; Fig. 3), but reef area and distance to seagrass were also of lesser importance to several fish. The effects of coral cover on reef fish abundance occurred over a narrow threshold, and abundance typically increased with coral cover between 10 and $30 \%$ (Fig. 3).
Connectivity with mangroves (at the 500 and 1000 $\mathrm{m}$ scales) was most important to the distribution of 7 reef fish species (Table 1 ). These included 2 snappers (Lutjanidae), a hardyhead (Atherinidae), a silverbiddy (Gerridae), a grouper (Serranidae), a rabbitfish (Siganidae) and a bream (Sparidae). Mangrove connectivity (i.e. separation distance and area of both habitats) was most important to 4 species and contributed between $35 \%$ (Epinephelus coioides) and $53 \%$ (Atherinomorus vaigiensis) to fish distributions on the reef. Mangrove isolation was also important for 4 species (contributing 11 to $33 \%$ ), and mangrove area was significant to Lutjanus fulviflamma (contributing $23 \%$ ). Reef complexity (i.e. coral cover and reef rugosity) was less important for all species (con- 
Pencil surgeonfish Acanthurus dussumieri
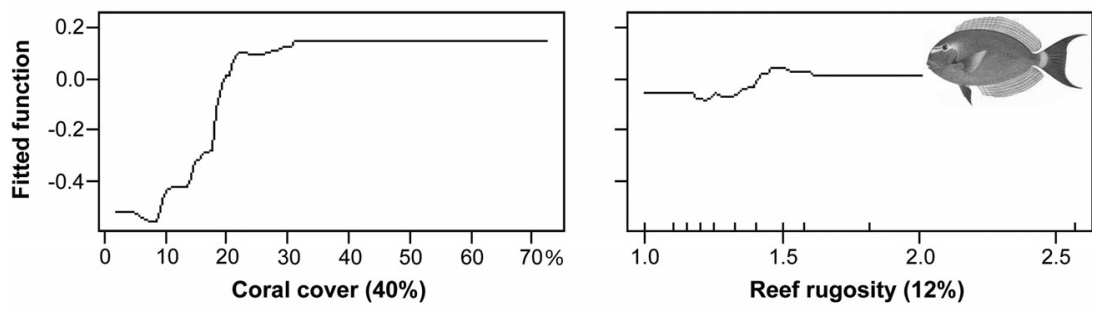

Moses snapper Lutjanus russelli
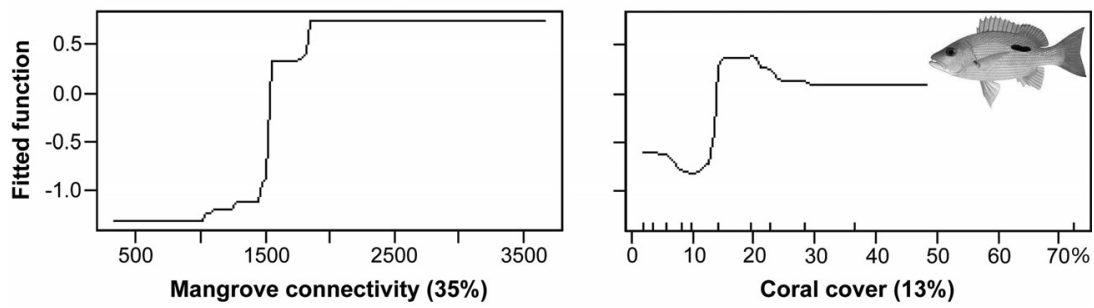

Bluebarred parrotfish Scarus ghobban
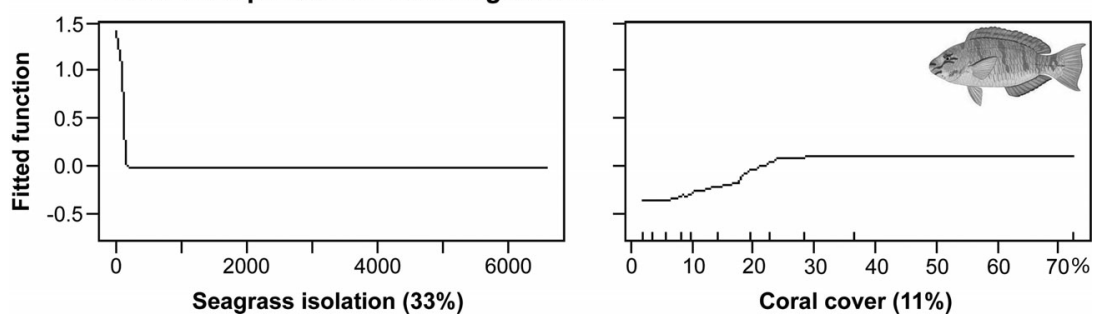

Fig. 3. Functions fitted in boosted regression trees (BRT) models relating the distribution of Acanthurus dussumieri, Lutjanus russelli and Scarus ghobban to the most important seascape connectivity and reef complexity metrics. The relative importance (percentage contribution) of each variable to BRT models is shown in parentheses on the $x$-axis (fish illustrations sourced from www.efishalbum.com)

tributing $<13 \%$ ). The LCE of reef with seagrass was also important to L. fulviflamma (contributing $11 \%$ ). The distribution of these mangrove-influenced species was centred on reefs with high connectivity to adjacent mangroves, and reef complexity was less important (e.g. Lutjanus russelli; Fig. 3). The effects of mangroves on reef fish abundance were manifest across a narrow threshold, and abundance declined sharply as mangrove isolation increased from 350 to $500 \mathrm{~m}$.

Connectivity with seagrass (at the 500 and $1000 \mathrm{~m}$ scales) was most important to the distribution of 7 species on reefs (Table 1). These included 2 emperors (Lethrinidae), a sweetlip (Haemulidae), a tuskfish (Labridae), a leatherjacket (Monacanthidae), a parrotfish (Scaridae) and a barracuda (Sphyraenidae). Seagrass proximity (i.e. separation distance and area of seagrass) was primarily important to 5 species and contributed between $24 \%$ (Diagramma labiosum) and $57 \%$ (Sphyraena obtusata) to fish distributions on the reef. Seagrass area (at $1000 \mathrm{~m}$ ) was important for 4 species (contributing 12 to $18 \%$ ), seagrass isolation was significant for 2 species (contributing 15 to $29 \%$ ), and seagrass LCE was important (contributing $35 \%$ ) to the distribution of Lethrinus nebulosus. Reef complexity was less important for all species (contributing <14\%). The distribution of these seagrass-influenced species was centred on reefs with high connectivity to adjacent seagrass, and reef complexity was less important (e.g. Scarus ghobban; Fig. 3). The effects of seagrass on reef fish abundance operated across a small range, with fish abundance increasing rapidly within $250 \mathrm{~m}$ of seagrass (Fig. 3).

Interactions between reef complexity and seascape connectivity predictors led to a more ecologically meaningful understanding of how multiple predictors interact to determine habitat suitability. Interactions were common among related seascape connectivity metrics (i.e. area and connectivity index) and reef complexity variables (i.e. coral cover and reef rugosity). Aside from this expected outcome, the models for Gerres subfasciatus, Monacanthus chinensis and $S$. obtusata involved the strongest interactions among predictors (Table 1). Interactions occurred between mangrove isolation and reef rugosity for $G$. subfasciatus, seagrass proximity and coral cover for $M$. chinensis and seagrass proximity and reef rugosity for S. obtusata. Interactions were relatively weak for the other species examined. Fish were characterised as reef-, mangrove- or seagrass-influenced species on the basis of BRT models (see Table 1). These categories were also used for interpretation of assemblage analyses.

\section{Reef fish assemblages and seascape connectivity}

Connectivity across the reef seascape correlated well with the overall composition of reef fish assemblages. Assemblages were best explained by their isolation from mangroves and coral cover at a scale of $250 \mathrm{~m}$ (BEST R value $=0.373, \mathrm{p}=0.01$ ) and by their isolation from mangroves, proximity to seagrass and coral cover at scales of $500(\mathrm{R}=0.520, \mathrm{p}=0.01)$ and 
$1000 \mathrm{~m}(\mathrm{R}=0.441, \mathrm{p}=0.01)$. Importantly, the maximum assemblage correlation (i.e. greatest $R$ value) occurred at a scale of $500 \mathrm{~m}$, and this provided the focus for subsequent LINKTREE analyses.

LINKTREE analysis produced a 7-leaf dendrogram to describe the influence of environmental variables (i.e. connectivity and reef complexity metrics) on the composition of reef fish assemblages (Fig. 4). Overall, the analysis demonstrated strong agreement with the BEST analyses but also illustrated a hierarchy in the relative importance of seascape connectivity and reef complexity variables. Highest order divisions among fish assemblages reflected isolation from mangroves, middle order splits related to proximity to seagrass, and all lower order partitions correlated with reef habitat variables (refer to coloured separations in Fig. 4). This suggests that reef fish assemblages in Moreton Bay were characterised first by their isolation from mangroves and then by their proximity to seagrass. This is visualised by the separation of sites into clusters based on their spatial relationship with both mangroves and seagrass. For example, reef fish assemblages at 4 sites (M2, S1, P1 and P4) were distinguished by being close to mangroves $(<250 \mathrm{~m})$ and far from seagrass (Fig. 4: high mangroves, low seagrass clusters). Assemblages at 3 sites (N1, C2 and G2) were characterised by being close to mangroves and close to large seagrass meadows (Fig. 4: high mangroves, high seagrass clusters) (site N1 was closer to a larger seagrass meadow). In contrast, assemblages at 4 sites (C1, C3, G1 and P5) were distinguished by being far from mangroves (>500 m) and close to large seagrass beds (Fig. 4: low mangroves, high seagrass clusters) (site C1 was further from mangroves and closer to a larger seagrass meadow). Assemblages at 5 sites (M1, S2, G3, P2 and P3) were characterised by being far from mangroves and far from seagrass (Fig. 4: low mangroves, low seagrass clusters).

Reef complexity (i.e. reef area and coral cover) had a lesser effect than seascape connectivity on the composition of reef fish assemblages (i.e. these variables

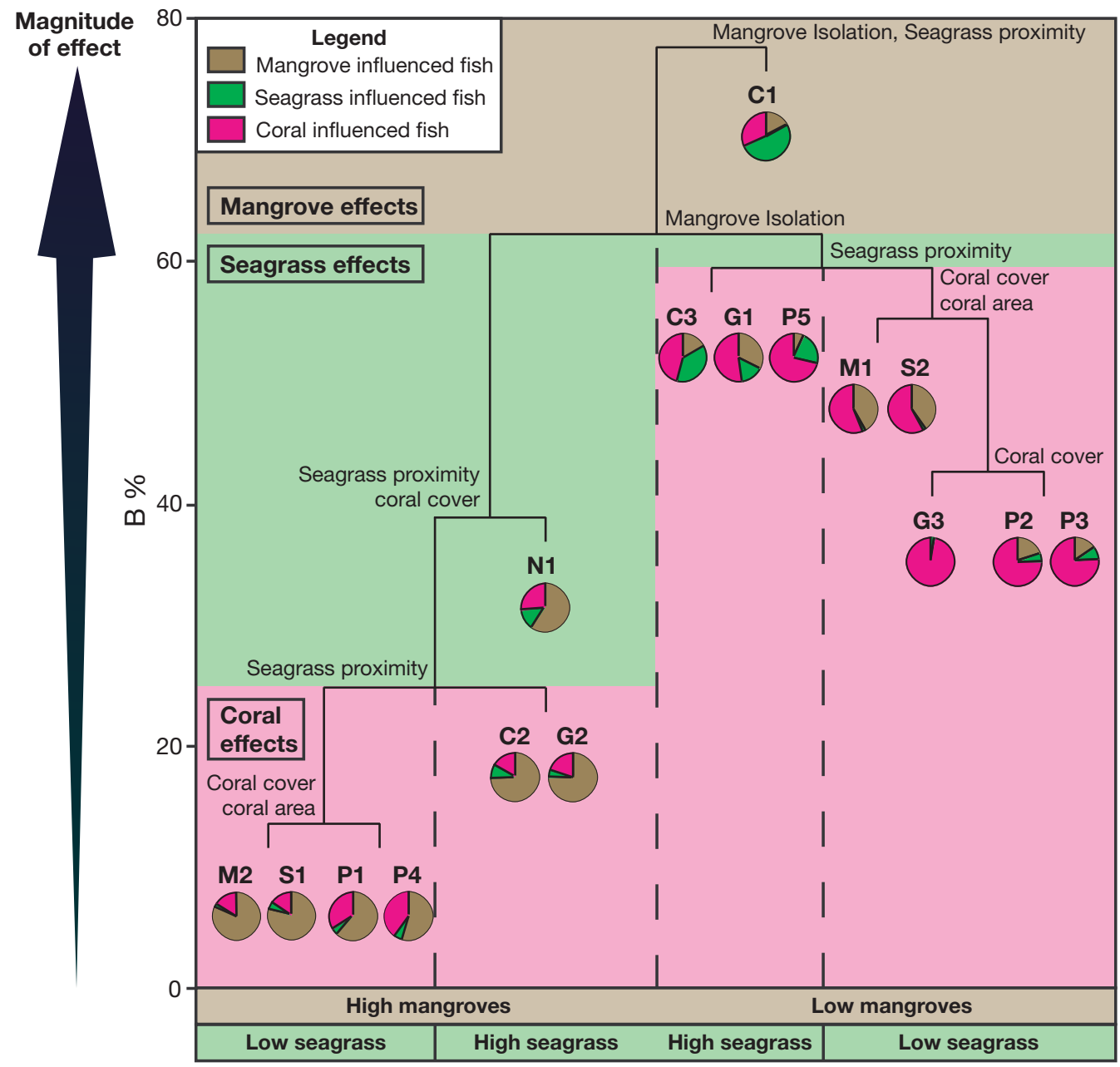

Fig. 4. Linkage tree (LINKTREE) of fish abundance from 16 reef locations. Plot displays tree divisions for which SIMPROF tests were significant $(\mathrm{p}<0.01)$; factors responsible for divisions are provided above each division. B\% (between-group separation scaled to 100) provides an absolute measure of group differences across divisions and a measure of the relative strength of seascape effects. Pie charts below terminal nodes display proportions of assemblages influenced by each habitat. High/low mangrove and high/low seagrass divisions denote reef assemblages with high/low connectivity to mangroves and seagrass, respectively. C: Coochiemudlo Island; G: Green Island; M: Mud Island; N: North Stradbroke Island; P: Peel Island; and S: St Helena Island 
were responsible for splits lower on the dendrogram) but had a greater influence on reefs further from mangroves (Fig. 4). The magnitude of this effect is visualised in Fig. 4 using pie charts, which represent the proportion of total fish abundance comprised of mangrove-, seagrass- and reef-influenced species. There were clear differences in assemblage composition among locations with different levels of connectivity with mangroves and seagrass, but little variation among locations on the basis of differences in coral cover or reef area.

\section{DISCUSSION}

The importance of adjacent habitats to reef fish populations has long been recognised. Early studies examined the ecology of off-reef feeding migrations (e.g. Randall 1965); more recently, research has focused on the role of seascape ecology in structuring reef fish assemblages (Grober-Dunsmore et al. 2009). Our findings show that there is a hierarchy in the correlation of reef fish assemblages with seascape connectivity. The composition of reef fish assemblages in Moreton Bay is primarily distinguished by their isolation from mangroves, secondarily by their proximity to seagrass, and only by reef habitat variables within each level of seascape connectivity. This result supports studies from the Caribbean, which have shown that the abundance, biomass and richness of reef fish species can be influenced by linkages with adjacent seagrass (e.g. Valentine et al. 2007, Nagelkerken et al. 2008) and mangrove habitats (e.g. Mumby et al. 2004, Nagelkerken 2007). It agrees with the conclusions of Grober-Dunsmore et al. (2008), who found that the area of neighbouring seagrass was more important to reef fish abundance than reef complexity. It also supports the findings of Pittman \& Brown (2011), who demonstrated that a reef's cross-shelf location can be more important to fish distributions than its topographic complexity. This finding cautions against management approaches that seek to conserve fish assemblages by focusing on reef structural complexity and is particularly relevant to the broader utility of remotely sensed fish-habitat relationships in coral reef ecosystems (reviewed by Mellin et al. 2009). We provide evidence that mangrove and seagrass habitats can indeed exert different effects on reef fish assemblages. This is manifest through species-specific relationships with different habitats and scales of seascape connectivity. Consequently, the magnitude of these effects might be expected to vary across different seascapes. In par- ticular, reef habitat variables might be more important on reefs that are more isolated or support greater coral diversity. However, we hypothesise that their effects may also be additive, with reefs in highly heterogeneous seascapes with high connectivity to both mangrove and seagrass habitats and high coral cover supporting greatest fish diversity and abundance. To strengthen this evidence for connectivity, we would ideally have also examined reefs lacking adjacent mangroves and seagrass, but this arrangement of habitats was not present in the studied system. Nevertheless, our findings support recommendations for adopting multi-scale hierarchical approaches when characterising the environmental drivers of reef fish biomass and diversity (e.g. MacNeil et al. 2009, Mellin et al. 2010a, Pittman \& Brown 2011). They have obvious implications for how we visualise connectivity in reef seascapes and important ramifications for how connectivity is coalesced into a management framework that seeks to both promote connectivity (Steneck et al. 2009) and enhance reef resilience (Hughes et al. 2010). This assertion is supported by recent findings that fish assemblages on small, isolated reefs may have higher temporal variability and lower resilience than those from larger, more connected reefs (Mellin et al. 2010b).

Our results imply that the principles of landscape ecology (sensu Forman \& Godron 1986), which have been applied in the reef seascapes of the Caribbean, warrant further investigation in the Pacific region. The spatial context of reefs relative to mangrove and seagrass habitats is important for the composition of reef fish assemblages in the Caribbean and Indian Ocean (reviewed by Grober-Dunsmore et al. 2009, Berkström et al. 2012), but there have been few comparable quantitative analyses on Pacific reefs (Nagelkerken 2007). Beger \& Possingham (2008) determined that isolation from the nearest estuary was a good predictor of reef fish distribution in Papua New Guinea. Similarly, Olds et al. (2012) demonstrated that connectivity with mangroves promoted the ability of marine reserves in Moreton Bay to enhance fish abundance. The focus of other studies in the Pacific, however, has been on assemblages in the seagrass (e.g. Jelbart et al. 2007, Unsworth et al. 2008) and mangrove (e.g. Pittman et al. 2004, Payne \& Gillanders 2009) habitats themselves. Our results suggest that seascape influences in the Pacific may affect reef fish from the same families as in the Caribbean (i.e. Haemulidae, Lutjanidae and Scaridae) (e.g. Nagelkerken 2007). It seems logical, therefore, that seascape connectivity may also structure ecological processes (e.g. Mumby \& Hastings 2008) and food webs (e.g. 
Heck et al. 2008, Nagelkerken et al. 2008) on Pacific reefs. However, given the geographic imbalance in studies of seascape connectivity (Nagelkerken 2007), there is now a need for further research testing the validity of these concepts across the wider Pacific. Furthermore, our results illustrate thresholds in the effects of mangrove and seagrass connectivity on reef fish abundance, with dramatic changes in fish abundance occurring with small decreases in mangrove (from 350 to $500 \mathrm{~m}$ ) and seagrass (below 250 $\mathrm{m})$ isolation. These thresholds concur with the scale at which diel and tidal connectivity is known to influence reef fish assemblages in the tropical Caribbean and Indian Ocean (e.g. Bostrom et al. 2011, Berkström et al. 2012) and have important implications for conservation planning and marine reserve design (sensu Olds et al. 2012).

For reefs in Moreton Bay, the primacy of mangrove connections over seagrass linkages and the performance of different metrics in describing these connections (i.e. isolation and connectivity with mangroves and proximity to seagrass) point to differences in their roles as fish habitat. Mangroves in Moreton Bay are used tidally by adult and sub-adult mangroveinfluenced reef fish but support few juveniles of these species (e.g. Tibbetts \& Connolly 1998, Olds et al. 2012). Blackspot snapper Lutjanus fulviflamma, moses snapper L. russelli and goldspotted rockcod Epinephelus coioides recruit to mangrove-lined creeks and shallow reefs as juveniles and migrate tidally to feed in mangroves before moving to offshore reefs at larger body sizes (e.g. Blaber 2000, Sheaves \& Molony 2000, Newman 2002, Meynecke et al. 2008a). Juvenile L. fulviflamma are also common in seagrass (Igulu et al. 2011). Yellowfin bream Acanthopagrus australis and black rabbitfish Siganus fuscescens recruit to seagrass, move to reefs (and other structurally complex habitat) as sub-adults (e.g. Griffiths 2001, Mellin et al. 2007, Meynecke et al. 2008a) and migrate tidally to feed in mangroves in Moreton Bay (Olds et al. 2012). Common hardyhead Atherinomorus vaigiensis and common silverbiddy Gerres subfasciatus also migrate tidally into mangroves to feed and seek refuge from predators (e.g. Laegdsgaard \& Johnson 2001). These fish use tidal streams to maximise time at the mangrove fringe, a pattern of mangrove use that is common for large mobile fish in tidal systems the world over (e.g. Sheaves 2009). Juvenile seagrass-influenced reef fish are common in seagrass adjoining the reefs in Moreton Bay, as are juveniles of some mangroveinfluenced species (e.g. Tibbetts \& Connolly 1998, E. Stone unpubl. data). Juvenile purple tuskfish
Choerodon cephalotes, grass and spangled emperor Lethrinus laticaudis and L. nebulosus, fanbelly leatherjacket Monacanthus chinensis and yellowtail barracuda Sphyraena obtusata occur in seagrass and migrate to reefs (and other structurally complex habitat) at larger sizes but often forage over seagrass (e.g. Blaber \& Blaber 1980, Warburton \& Blaber 1992, Wilson 1998, Fairclough et al. 2008). Similarly, painted sweetlip Diagramma labiosum and bluebarred parrotfish Scarus ghobban recruit to shallow seagrass and adjacent reefs, move to reefs as adults and feed in adjacent seagrass and soft-bottom habitats (e.g. Dorenbosch et al. 2005a,b, Mellin et al. 2007, Grandcourt et al. 2011). It is difficult to separate the potential drivers of these seascape linkages (e.g. ontogenetic or feeding migrations), but given the size distribution of fish in each habitat (and the habitat requirements of each species), we speculate that mangroves in Moreton Bay are important foraging locations for reef fish, while the value of seagrass primarily reflects its use as a juvenile nursery (sensu Beck et al. 2001). A potential differentiation of ecological roles among these 2 nursery habitats, however, would have significant implications for the way we conceptualise and manage nurseries for juvenile reef fish.

Our results suggest a hierarchy in the correlation of reef fish assemblages with seascape connectivity, with composition being primarily driven by isolation from mangroves, secondarily by proximity to seagrass and then by reef habitat variables within each of these connectivity groups. We demonstrate that mangrove and seagrass habitats can exert different effects on reef fish assemblages and have more influence on reef fish abundance than the complexity of the reef itself. These findings have important implications for the design of marine reserve networks, the way we conceptualise nursery habitats for juvenile reef fish and the management of mobile exploited populations across reef seascapes. They show that position in the seascape can be more significant than reef area or complexity to the composition of reef fish assemblages and highlight the value of incorporating seascape connectivity into conservation planning.

Acknowledgements. We thank H. Faddy, T. Lavery, B. Moore, M. Olds and E. Stone for field assistance, R. Babcock and D. Rissik for advice about reserves and S. Albert, C. Beattie, H. Faddy and C. Huijbers for comments on the manuscript. This work was funded by an Australian Research Council grant (to R.M.C. and K.A.P.) in collaboration with the Queensland Department of Environment and Resource Management. 


\section{LITERATURE CITED}

Adams AJ, Dahlgren CP, Kellison GT, Kendall MS and others (2006) Nursery function of tropical back-reef systems. Mar Ecol Prog Ser 318:287-301

Almany GR, Connolly SR, Heath DD, Hogan JD and others (2009) Connectivity, biodiversity conservation and the design of marine reserve networks for coral reefs. Coral Reefs 28:339-351

> Beck MW, Heck KL, Able KW, Childers DL and others (2001) The identification, conservation, and management of estuarine and marine nurseries for fish and invertebrates. Bioscience 51:633-641

Beger M, Possingham H (2008) Environmental factors that influence the distribution of coral reef fishes: modeling occurrence data for broad-scale conservation and management. Mar Ecol Prog Ser 361:1-13

> Berkström C, Gullström M, Lindborg R, Mwandya AW, Yahya SA, Kautsky N, Nyström M (2012) Exploring 'knowns' and 'unknowns' in tropical seascape connectivity: a review with insights from east African coral reefs. Estuar Coast Shelf Sci 107:1-21

Blaber SJM (2000) Fish faunas and communities. In: Blaber SJM (ed) Tropical estuarine fishes: ecology, exploitation, and conservation. Blackwell Science, Malden, p 40-95

> Blaber SJM, Blaber TG (1980) Factors affecting the distribution of juvenile estuarine and inshore fish. J Fish Biol 17: 143-162

Bostrom C, Pittman SJ, Simenstad C, Kneib RT (2011) Seascape ecology of coastal biogenic habitats: advances, gaps, and challenges. Mar Ecol Prog Ser 427:191-217

Calabrese JM, Fagan WF (2004) A comparison-shopper's guide to connectivity metrics. Front Ecol Environ 2: 529-536

> Chateau O, Wantiez L (2009) Movement patterns of 4 coral reef fish species in a fragmented habitat in New Caledonia: implications for the design of marine protected area networks. ICES J Mar Sci 66:50-55

Clarke KR, Somerfield PJ, Gorley RN (2008) Testing of null hypotheses in exploratory community analyses: similarity profiles and biota-environment linkage. J Exp Mar Biol Ecol 366:56-69

> De'ath G (2007) Boosted trees for ecological modeling and prediction. Ecology 88:243-251

> Dorenbosch M, Christianen MJA, Nagelkerken I, van der Velde G (2005a) Indo-Pacific seagrass beds and mangroves contribute to fish density and diversity on adjacent coral reefs. Mar Ecol Prog Ser 302:63-76

> Dorenbosch M, Grol MGG, Nagelkerken I, van der Velde G (2005b) Distribution of coral reef fishes along a coral reef-seagrass gradient: edge effects and habitat segregation. Mar Ecol Prog Ser 299:277-288

> Dorenbosch M, Grol MGG, de Groene A, van der Velde G, Nagelkerken I (2009) Piscivore assemblages and predation pressure affect relative safety of some back-reef habitats for juvenile fish in a Caribbean bay. Mar Ecol Prog Ser 379:181-196

Dowling R, Stephens K (2001) Coastal wetlands of south east Queensland mapping and survey, Vol 1. Queensland Herbarium, Brisbane

Elith J, Leathwick J (2011) Boosted regression trees for ecological modeling: documentation on the $\mathrm{R}$ Package 'dismo', version 0.7-17. http://cran.r-project.org/web/ packages/dismo/index.html (accessed March 2012)

Elith J, Leathwick JR, Hastle T (2008) A working guide to boosted regression trees. J Anim Ecol 77:802-813

> Fairclough DV, Clarke KR, Valesini FJ, Potter IC (2008) Habitat partitioning by 5 congeneric and abundant Choerodon species (Labridae) in a large subtropical marine embayment. Estuar Coast Shelf Sci 77:446-456

Forman RTT, Godron M (1986) Landscape ecology. Wiley, New York, NY

Fox RJ, Bellwood DR (2011) Unconstrained by the clock? Plasticity of diel activity rhythm in a tropical reef fish, Siganus lineatus. Funct Ecol 25:1096-1105

Fulton CJ, Bellwood DR, Wainwright PC (2001) The relationship between swimming ability and habitat use in wrasses (Labridae). Mar Biol 139:25-33

Grandcourt EM, Al Abdessalaam TZ, Francis F, Al Shamsi AT (2011) Reproductive biology and implications for management of the painted sweetlips Diagramma pictum in the southern Arabian Gulf. J Fish Biol 79:615-632

Griffiths SP (2001) Recruitment and growth of juvenile yellowfin bream, Acanthopagrus australis Günther (Sparidae), in an Australian intermittently open estuary. J Appl Ichthyology 17:240-243

- Grober-Dunsmore R, Frazer TK, Lindberg WJ, Beets J (2007) Reef fish and habitat relationships in a Caribbean seascape: the importance of reef context. Coral Reefs 26: 201-216

Grober-Dunsmore R, Frazer TK, Beets JP, Lindberg WJ, Zwick P, Funicelli NA (2008) Influence of landscape structure on reef fish assemblages. Landscape Ecol 23: $37-53$

Grober-Dunsmore R, Pittman SJ, Caldow C, Kendall MS, Frazer TK (2009) A landscape ecology approach for the study of ecological connectivity across tropical marine seascapes. In: Nagelkerken I (ed) Ecological connectivity among tropical coastal ecosystems. Springer, Heidelberg, p 493-530

- Heck KL Jr, Carruthers TJB, Duarte CM, Hughes AR, Kendrick G, Orth RJ, Williams SW (2008) Trophic transfers from seagrass meadows subsidize diverse marine and terrestrial consumers. Ecosystems 11:1198-1210

> Hodgson JA, Thomas CD, Wintle BA, Moilanen A (2009) Climate change, connectivity and conservation decision making: back to basics. J Appl Ecol 46:964-969

> Hughes TP, Graham NAJ, Jackson JBC, Mumby PJ, Steneck RS (2010) Rising to the challenge of sustaining coral reef resilience. Trends Ecol Evol 25:633-642

Huntington BE, Karnauskas M, Babcock EA, Lirman D (2010) Untangling natural seascape variation from marine reserve effects using a landscape approach. PLoS ONE 5:e12327

Igulu MM, Nagelkerken I, Fraaije R, van Hintum R, Ligtenberg H, Mgaya YD (2011) The potential role of visual cues for microhabitat selection during the early life phase of a coral reef fish (Lutjanus fulviflamma). J Exp Mar Biol Ecol 401:118-125

> Jelbart JE, Ross PM, Connolly RM (2007) Fish assemblages in seagrass beds are influenced by the proximity of mangrove forests. Mar Biol 150:993-1002

Johnson PR, Neil DT (1998) The corals of Moreton Bay: living with extremes. In: Tibbetts IR, Hall NJ, Dennison WC (eds) Moreton Bay and catchment. University of Queensland, Brisbane, p 503-524

Jones GP, Almany GR, Russ GR, Sale PF, Steneck RS, Oppen MJH, Willis BL (2009) Larval retention and connectivity among populations of corals and reef fishes: history, advances and challenges. Coral Reefs 28:307-325 
Kendall MS, Miller TJ, Pittman SJ (2011) Patterns of scaledependency and the influence of map resolution on the seascape ecology of reef fish. Mar Ecol Prog Ser 427: 259-274

Kindlmann P, Burel F (2008) Connectivity measures: a review. Landscape Ecol 23:879-890

Knowlton N, Jackson JBC (2008) Shifting baselines, local impacts, and global change on coral reefs. PLoS Biol 6: e54

Knudby A, Brenning A, LeDrew E (2010) New approaches to modelling fish-habitat relationships. Ecol Model 221: 503-511

> Kohler KE, Gill SM (2006) Coral point count with excel extensions (CPCe): a visual basic program for the determination of coral and substrate coverage using random point count methodology. Comput Geosci 32:1259-1269

> Laegdsgaard P, Johnson CR (2001) Why do juvenile fish utilise mangrove habitats? J Exp Mar Biol Ecol 257: 229-253

Layman CA, Quattrochi JP, Peyer CM, Allgeier JE (2007) Niche width collapse in a resilient top predator following ecosystem fragmentation. Ecol Lett 10:937-944

Lindenmayer DB, Fischer J (2007) Tackling the habitat fragmentation panchreston. Trends Ecol Evol 22:127-132

> Luckhurst BE, Luckhurst K (1978) Analysis of the influence of substrate variables on coral reef fish communities. Mar Biol 49:317-323

Lybolt M, Neil D, Zhao J, Feng Y, Yu K, Pandolfi J (2011) Instability in a marginal coral reef: the shift from natural variability to a human-dominated seascape. Front Ecol Environ 9:154-160

Lyons M, Phinn S, Roelfsema C (2011) Integrating quickbird multi-spectral satellite and field data: mapping bathymetry, seagrass cover, seagrass species and change in Moreton Bay, Australia in 2004 and 2007. Remote Sens 3: 42-64

MacNeil MA, Graham NAJ, Polunin NVC, Kulbicki M, Galzin R, Harmelin-Vivien M, Rushton SP (2009) Hierarchical drivers of reef-fish metacommunity structure. Ecology 90:252-264

> McCook LJ, Almany GR, Berumen ML, Day JC and others (2009) Management under uncertainty: guide-lines for incorporating connectivity into the protection of coral reefs. Coral Reefs 28:353-366

McGarigal K, Cushman SA, Neel MC, Ene E (2002) FRAGSTATS: spatial pattern analysis program for categorical maps. University of Massachusetts, Amherst

> Mellin C, Kulbicki M, Ponton D (2007) Seasonal and ontogenetic patterns of habitat use in coral reef fish juveniles. Estuar Coast Shelf Sci 75:481-491

> Mellin C, Andréfou t S, Kulbicki M, Dalleau M, Vigliola L (2009) Remote sensing and fish-habitat relationships in coral reef ecosystems: review and pathways for multiscale hierarchical research. Mar Pollut Bull 58:11-19

Mellin C, Bradshaw CJA, Meekan MG, Caley MJ (2010a) Environmental and spatial predictors of species richness and abundance in coral reef fishes. Glob Ecol Biogeogr 19:212-222

- Mellin C, Huchery C, Caley MJ, Meekan MG, Bradshaw CJA (2010b) Reef size and isolation determine the temporal stability of coral reef fish populations. Ecology 91: 3138-3145

> Meynecke J, Poole G, Werry J, Lee S (2008a) Use of PIT tag and underwater video recording in assessing estuarine fish movement in a high intertidal mangrove and salt marsh creek. Estuar Coast Shelf Sci 79:168-178

Meynecke JO, Lee SY, Duke NC (2008b) Linking spatial metrics and fish catch reveals the importance of coastal wetland connectivity to inshore fisheries in Queensland, Australia. Biol Conserv 141:981-996

Moilanen A, Nieminen M (2002) Simple connectivity measures in spatial ecology. Ecology 83:1131-1145

> Mumby P (2006) Connectivity of reef fish between mangroves and coral reefs: algorithms for the design of marine reserves at seascape scales. Biol Conserv 128: 215-222

> Mumby PJ, Hastings A (2008) The impact of ecosystem connectivity on coral reef resilience. J Appl Ecol 45:854-862

Mumby PJ, Edwards AJ, Arias-Gonzalez JE, Lindeman KC and others (2004) Mangroves enhance the biomass of coral reef fish communities in the Caribbean. Nature 427:533-536

Nagelkerken I (2007) Are non-estuarine mangroves connected to coral reefs through fish migration? Bull Mar Sci 80:595-607

Nagelkerken I (2009) Evaluation of nursery function of mangroves and seagrass beds for tropical decapods and reef fishes: patterns and underlying mechanisms. In: Nagelkerken I (ed) Ecological connectivity among tropical coastal ecosystems. Springer, Heidelberg, p 357-399

Nagelkerken I, Bothwell J, Nemeth RS, Pitt JM, van der Velde G (2008) Interlinkage between Caribbean coral reefs and seagrass beds through feeding migrations by grunts (Haemulidae) depends on habitat accessibility. Mar Ecol Prog Ser 368:155-164

Newman SJ (2002) Growth, age estimation and preliminary estimates of longevity and mortality in the moses perch, Lutjanus russelli (Indian Ocean form), from continental shelf waters off north-western Australia. Asian Fish Sci 15:283-294

> Olds AD, Connolly RM, Pitt KA, Maxwell PS (2012) Habitat connectivity improves reserve performance. Conserv Lett 5:56-63

Payne NL, Gillanders BM (2009) Assemblages of fish along a mangrove-mudflat gradient in temperate Australia. Mar Freshw Res 60:1-13

Pittman SJ, Brown KA (2011) Multi-scale approach for predicting fish species distributions across coral reef seascapes. PLoS ONE 6:e20583

Pittman SJ, McAlpine CA, Pittman KM (2004) Linking fish and prawns to their environment: a hierarchical landscape approach. Mar Ecol Prog Ser 283:233-254

> Pittman SJ, Costa BM, Battista TA (2009) Using lidar bathymetry and boosted regression trees to predict the diversity and abundance of fish and corals. J Coast Res 53:27-38

Pittman SJ, Kneib RT, Simenstad CA (2011) Practicing coastal seascape ecology. Mar Ecol Prog Ser 427:187-190

R Core Development Team (2012) R: a language and environment for statistical computing. R Foundation for Statistical Computing, Vienna

Randall JE (1965) Grazing effect on sea grasses by herbivorous reef fishes in the West Indies. Ecology 46:255-260

Roelfsema CM, Phinn SR, Udy N, Maxwell P (2009) An integrated field and remote sensing approach for mapping seagrass cover, Moreton Bay, Australia. J Spatial Sci 54: 45-62

Sheaves MJ (1993) Patterns of movement of some fishes within an estuary in tropical Australia. Mar Freshw Res 44:867-880 
Sheaves M (2009) Consequences of ecological connectivity: the coastal ecosystem mosaic. Mar Ecol Prog Ser 391: $107-115$

Sheaves M, Molony B (2000) Short-circuit in the mangrove food chain. Mar Ecol Prog Ser 199:97-109

Skilleter GA, Olds A, Loneragan NR, Zharikov Y (2005) The value of patches of intertidal seagrass to prawns depends on their proximity to mangroves. Mar Biol 147:353-365

Steneck RS, Paris CB, Arnold SN, Ablan-Lagman MC and others (2009) Thinking and managing outside the box: coalescing connectivity networks to build region-wide resilience in coral reef ecosystems. Coral Reefs 28: 367-378

Stevens T, Connolly RM (2005) Local-scale mapping of benthic habitats to assess representation in a marine protected area. Mar Freshw Res 56:111-123

Tibbetts IR, Connolly RM (1998) The nekton of Moreton Bay. In: Tibbetts IR, Hall NJ, Dennison WC (eds) Moreton Bay and catchment. University of Queensland, Brisbane, p 395-420

Treml EA, Halpin PN, Urban DL, Pratson LF (2008) Modeling population connectivity by ocean currents, a graphtheoretic approach for marine conservation. Landscape Ecol 23:19-36

Unsworth RKF, Cullen LC (2010) Recognising the necessity for Indo-Pacific seagrass conservation. Conserv Lett 3: 63-73

Unsworth RKF, De León PS, Garrard SL, Jompa J, Smith DJ, Bell JJ (2008) High connectivity of Indo-Pacific seagrass fish assemblages with mangrove and coral reef habitats. Mar Ecol Prog Ser 353:213-224

Valentine JF, Heck KL Jr (2005) Perspective review of the impacts of overfishing on coral reef food web linkages. Coral Reefs 24:209-213

- Valentine JF, Heck KL Jr, Blackmon D, Goecker ME and others (2007) Food web interactions along seagrass-coral reef boundaries: effects of piscivore reductions on crosshabitat energy exchange. Mar Ecol Prog Ser 333:37-50

Wallace CC, Fellegara I, Muir PR, Harrison PL (2009) The scleractinian corals of Moreton Bay, eastern Australia: high latitude, marginal assemblages with increasing species richness. Mem Queensl Mus 54:1-118

Warburton K, Blaber SJM (1992) Patterns of recruitment and resource use in a shallow-water fish assemblage in Moreton Bay, Queensland. Mar Ecol Prog Ser 90: 113-126

> Wedding LM, Lepczyk CA, Pittman SJ, Friedlander AM, Jorgensen S (2011) Quantifying seascape structure: extending terrestrial spatial pattern metrics to the marine realm. Mar Ecol Prog Ser 427:219-232

Wilson GG (1998) A description of the early juvenile colour patterns of eleven Lethrinus species (Pisces: Lethrinidae) from the Great Barrier Reef, Australia. Rec Aust Mus 50: $55-83$

> Wilson SK, Graham NAJ, Polunin NVC (2007) Appraisal of visual assessments of habitat complexity and benthic composition on coral reefs. Mar Biol 151:1069-1076

Wilson SK, Adjeroud M, Bellwood DR, Berumen ML and others (2010) Crucial knowledge gaps in current understanding of climate change impacts on coral reef fishes. J Exp Biol 213:894-900

Zeller D, Stoute SL, Russ GR (2003) Movements of reef fishes across marine reserve boundaries: effects of manipulating a density gradient. Mar Ecol Prog Ser 254:269-280

Appendix 1. Optimal settings and predictive performance of boosted regression tree (BRT) models. NT: number of trees; LR: learning rate; TC: tree complexity; AUC: area under the receiver operating characteristic curve. Only species with fitted models with acceptable predictive performance (i.e. AUC $\geq 0.7$ ) are reported. The bag fraction was set at the default 0.50 for all models (bag fraction controls the level of stochasticity in BRT models and specifies the proportion of data to be selected at each step)

\begin{tabular}{|c|c|c|c|c|c|c|c|c|c|}
\hline Species & NT & LR & $\mathrm{TC}$ & AUC & Species & NT & LR & $\mathrm{TC}$ & AUC \\
\hline Abudefduf bengalensis & 5700 & 0.0007 & 3 & 0.860 & Epinephelus coioides & 2550 & 0.0009 & 2 & 0.827 \\
\hline Acanthopagrus australis & 5800 & 0.0006 & 3 & 0.860 & Gerres subfasciatus & 9400 & 0.0005 & 3 & 0.927 \\
\hline Acanthurus dussumieri & 1000 & 0.0009 & 3 & 0.707 & Lethrinus laticaudis & 3800 & 0.0005 & 3 & 0.878 \\
\hline Apogon limenus & 5200 & 0.0007 & 3 & 0.867 & Lethrinus nebulosus & 6350 & 0.0004 & 4 & 0.837 \\
\hline Atherinomorus vaigiensis & 9250 & 0.0002 & 2 & 0.847 & Lutjanus fulviflamma & 6050 & 0.0005 & 3 & 0.895 \\
\hline Chaetodon auriga & 3800 & 0.0006 & 3 & 0.826 & Lutjanus russelli & 3950 & 0.001 & 3 & 0.892 \\
\hline Chaetodon flavirostris & 8700 & 0.0003 & 3 & 0.886 & Monacanthus chinensis & 8000 & 0.0005 & 3 & 0.823 \\
\hline Chaetodon melannotus & 6150 & 0.0004 & 3 & 0.833 & Parma oligolepis & 7950 & 0.0007 & 3 & 0.904 \\
\hline Chaetodon plebeius & 3200 & 0.0008 & 3 & 0.824 & Pentapodus paradiseus & 2050 & 0.0009 & 3 & 0.708 \\
\hline Cheilodactylus vestitus & 5950 & 0.0006 & 3 & 0.881 & Prionurus microlepidotus & 4000 & 0.0006 & 3 & 0.715 \\
\hline Chelmon rostratus & 3850 & 0.0009 & 3 & 0.891 & Scarus ghobban & 6500 & 0.0006 & 3 & 0.865 \\
\hline Choerodon cephalotes & 1500 & 0.001 & 2 & 0.728 & Siganus fuscescens & 8350 & 0.0005 & 3 & 0.871 \\
\hline Choerodon schoenleinii & 8850 & 0.0001 & 4 & 0.704 & Sphyraena obtusata & 9650 & 0.0004 & 3 & 0.862 \\
\hline Diagramma labiosum & 6800 & 0.0003 & 3 & 0.820 & Thalassoma lunare & 3850 & 0.0009 & 3 & 0.903 \\
\hline
\end{tabular}

